\title{
KONSTRUKSI INSTRUMEN PENGUKURAN KONFLIK PEKERJAAN KELUARGA PADA IBU YANG BEKERJA: BERBASIS PENDEKATAN INDIGENOUS
}

\section{CONSTRUCTION OF MEASUREMENT INSTRUMENTS WORK-FAMILY CONFLICT FOR WORKING MOTHERS: INDIGENOUS PSYCHOLOGY APPROACH}

\author{
Triana Noor Edwina Dewayani Soeharto ${ }^{1}$, Muhammad Wahyu Kuncoro², \\ Sowanya Ardi Prahara ${ }^{3}$ \\ ${ }^{123}$ Universitas Mercu Buana Yogyakarta \\ 11winasoeharto@gmail.com
}

\begin{abstract}
Abstrak
Penelitian ini bertujuan untuk mengembangkan skala konflik pekerjaan-keluarga yang dialami ibu yang bekerja pada istri yang bekerja berbasis pendekatan psikologi indigenous Melalui pendekatan psikologi indigenous diharapkan dapat menciptakan instrumen pengukuran psikologi dengan aspek yang lebih konstektual. Penelitian ini dilakukan di Daerah Istimewa Yogyakarta (DIY) karena DIY merupakan salah satu pusat budaya Jawa. Karakteristik subyek penelitian adalah istri yang mengidentifikasikan dirinya sebagai etnis Jawa mempunyai anak yang berusia di bawah 12 tahun yang tinggal bersama suami, bekerja sebagai tenaga profesional sebanyak 292. Pengumpulan data penelitian menggunakan skala konflik pekerjaankeluarga yang dialami ibu yang bekerja, penulisan aitem skala ini mengacu pada aspek hasil temuan dari penelitian dengan pendekatan psikologi indigenous untuk mengeksplorasi konstrak konflik pekerjaankeluarga. Berdasarkan analisis dengan menggunakan model persamaan struktural yaitu SEM (Struktural Equation Modeling) diperoleh instrumen konflik pekerjaan-keluarga yang dialami ibu yang bekerja pada istri yang bekerja berbasis pendekatan psikologi indigenous. Kontribusi terbesar pada variabel konflik pekerjaankeluarga adalah dimensi rekan kerja dan yang terendah adalah beban kerja.
\end{abstract}

Kata Kunci: konflik pekerjaan-keluarga ibu yang bekerja, pendekatan psikologi indigenous.

\begin{abstract}
This research aims to develop the scale of work-family conflict experienced by mothers working on a working wife based on indigenous psychology-approach. Through indigenous psychology, the approach is expected to create psychological measurement instruments with more contextual aspects. This study was conducted in Yogyakarta (DIY) because Yogyakarta is one of the cultural centers of Java. Characteristics of the study subjects were wife identify themselves as Javanese ethnic who have children aged under 12 years living together husband, 292 wives worked as professionals. Data collection of this study is using the scale of workfamily conflict experienced by working mothers, item writing of this scale refers to the aspect of the findings of the study with indigenous psychology approach to explore the construct of work-family conflict. Based on the data analysis SEM (Structural Equation Modeling) found the work-family conflict instrument experienced by mothers who are working wife based on the indigenous psychology approach. The biggest contribution to the work-family conflict variable is the colleague dimension and the lowest is the workload.
\end{abstract}

Keywords: work-family conflict on working mothers; indigenous psychology approach.

\section{PENDAHULUAN}

Selama beberapa tahun terakhir, peningkatan jumlah penduduk yang bekerja didominasi oleh perempuan. Jika dilihat berdasarkan jumlah angkatan kerja, selama periode 2006-2008 peningkatan jumlah angkatan kerja perempuan jauh lebih besar dibandingkan dengan peningkatan jumlah angkatan kerja laki-laki. Jumlah angkatan kerja perempuan pada tahun 2006 mencapai 38,6 juta

DOI : https://dx.doi.org/10.26486/psikologi.v22i2.1149

URL : http://ejurnal.mercubuana-yogya.ac.id/index.php/psikologi/index

Email : insight@mercubuana-yogya.ac.id 
orang dan meningkat hingga 42,8 juta orang pada tahun 2008, sementara angkatan kerja laki-laki meningkat dari 67,7 juta orang menjadi 69,1 juta orang dalam waktu yang sama. Tahun 2009, peningkatan penduduk perempuan yang bekerja sebesar 3,26 juta orang sedangkan peningkatan penduduk laki-laki yang bekerja hanya sebesar 1,21 juta orang (Badan Pusat Statistik, 2009).

Semakin meluasnya peran perempuan dalam sektor publik akan menimbulkan permasalahan dalam diri perempuan. Apabila perempuan yang bekerja menikah dan mempunyai anak ikut membantu mencari nafkah di sektor publik tetapi beban domestik tidak berkurang maka tanggungjawab perempuan tersebut menjadi berganda (Noor, 2002). Peran yang diharapkan dari perempuan belum banyak berubah. Perempuan yang bekerja masih diharapkan bertanggung jawab untuk tugas-tugas rumah. Perempuan yang bekerja mendapat sedikit bantuan dari suami, yang menganggap tugas utama suami dalam keluarga terbatas untuk mencari nafkah dan melindungi keluarga.

Dalam budaya Indonesia, seperti juga di banyak negara dunia ketiga lain, budaya patriarki masih sangat kental. Patriarki merupakan struktur yang mengabsahkan bentuk struktur kekuasaan lelaki mendominasi perempuan (Koentjaraningrat, 1974). Sistem patriarki memisahkan peran utama antara lelaki dan perempuan dalam keluarga. Budaya tersebut masih sangat kental dan mewarnai berbagai aspek kehidupan dan struktur masyarakat serta menciptakan ketimpanganketimpangan gender. Ketidaksetaraan peran perempuan dan laki-laki membuat perempuan yang bekerja lebih mengalami konflik pekerjaan-keluarga.

Konflik pekerjaan dan keluarga diartikan oleh Hill, Yang, Hawkins, dan Ferris, (2004) sebagai bentuk konflik antar peran, peran yang dituntut dalam pekerjaan dan keluarga akan saling mempengaruhi. Pemenuhan peran dalam pekerjaan/keluarga akan menimbulkan kesulitan untuk memenuhi peran keluarga/pekerjaan (Greenhaus \& Butell dalam (Hill, dkk., 2004); Voydanoff, 2004).

Menurut Huang, Hammer, Neal, dan Perrin, (2004) dan Noor (2004) konflik pekerjaan dan keluarga mempunyai dua demensi: konflik pekerjaan-keluarga: Konflik pekerjaan-keluarga adalah pemenuhan peran dalam pekerjaan dapat menimbulkan kesulitan pemenuhan peran dalam keluarga (Huang, dkk., 2004; Noor, 2004) dan konflik keluarga-pekerjaan : Konflik keluarga dan pekerjaan disebabkan ada faktor dalam keluarga yang menyebabkan masalah dalam pekerjaan (Hammer, Neal, Newson, Brockwood, \& Colton, 2005). Lebih lanjut, konflik kelurga dan pekerjaan terjadi karena tanggung jawab dalam keluarga menghambat aktivitas kerja.

Pendekatan psikologi indigenous merupakan suatu pendekatan yang menekankan pada studi terhadap perilaku dan cara berpikir seseorang yang menggunakan perspektif asli dan tidak diadopsi dari daerah lainnya agar data yang diperoleh asli dalam realitas Indonesia sendiri (Faturochman, Minza, \& Nurjaman, 2017). Konstrak konflik pekerjaan-keluarga pada ibu yang bekerja dibangun berdasarkan pemahaman terhadap manusia pada konteks lokal (Indigenous) sehingga hasil penelitian yang didapatkan benar-benar murni pemahaman terhadap manusia Indonesia dapat 
diaplikasikan sesuai konteks budaya Indonesia, bukan semata-mata adopsi dari teori-teori yang berkembang di negara lain.

Hingga saat ini belum ada instrumen pengukuran konflik keluarga berbasis pendekatan di Indonesia. Melalui pendekatan psikologi indigenous diharapkan dapat menciptakan instrument pengukuran psikologi dengan dimensi atau aspek-aspek yang lebih kontekstual sehingga dapat memotret suatu fenomena sosial berdasar kontekstualnya.

Penyusunan skala ini didasarkan pada pengumpulan data penelitian yang menggunakan instrument pengukuran psikologi dengan konstrak konflik pekerjaan-keluarga yang dialami ibu yang bekerja pada istri yang bekerja yang telah ditemukan pada penelitian dilakukan penulis yang bertujuan eksplorasi konstrak konflik pekerjaan-keluarga yang dialami ibu yang bekerja (dalam keluarga Jawa) berbasis pendekatan psikologi indigenous.

Dari hasil penelitian Soeharto dan Kuncoro (2015) diketemukan konstrak konflik pekerjaankeluarga sebagai berikut: 1) beban kerja, 2) jarak tempat kerja, 3) kondisi tempat kerja, 4) hubungan dengan pimpinan, dan 5) hubungan dengan rekan kerja. Oleh karena itu, penelitian ini bertujuan untuk melakukan konstruksi Skala Konflik Pekerjaan-Keluarga yang dialami ibu yang bekerja berbasis pendekatan psikologi indigenous.

\section{METODE}

Penelitian ini dilakukan di Daerah Istimewa Yogyakarta (DIY) karena DIY merupakan salah satu pusat budaya Jawa. Subyek penelitian dalam penelitian ini adalah istri yang mengidentifikasikan dirinya sebagai etnis Jawa dan tinggal bersama suami, mempunyai anak yang berusia di bawah 12 tahun yang tinggal bersama, istri bekerja sebagai tenaga professional. Survei dilakukan terhadap 292 pasangan yang tinggal di Wilayah Daerah Istimewa Yogyakarta.

Jenis penelitian adalah metode penelitian survei dilakukan untuk mengeksplorasi konstrak konflik pekerjaan-keluarga sehingga dapat disusun konstrak konflik konflik pekerjaan-keluarga pada ibu yang bekerja (dalam keluarga Jawa).

Pengumpulan data penelitian dilakukan melalui metode survey menggunakan instrument/skala konflik pekerjaan-keluarga untuk menguji dimensi konstrak konflik pekerjaankeluarga. Skala konflik pekerjaan-keluarga yang akan diuji disusun atas 5 dimensi yaitu a) beban kerja, b) jarak tempat kerja, c) kondisi tempat kerja, d) hubungan dengan pimpinan, dan e) hubungan dengan rekan kerja. Masing-masing dimensi diungkap oleh 2 butir aitem, sehingga jumlah aitem untuk mengungkap konstrak konflik pekerjaan-keluarga sebanyak 20 aitem.

Pada penelitian ini menggunakan model persamaan struktural yaitu SEM (Struktural Equation Modeling), yaitu sekumpulan teknik-teknik statistikal yang memungkinkan pengujian sebuah rangkaian hubungan yang relatif rumit secara simultan. Model pengukuran menggunakan SEM, dipakai untuk menganalisis data yang diperoleh pada penelitian yang sebenarnya yaitu untuk menguji ketepatan model yang diajukan dalam suatu penelitian (Ghozali, 2008). Analisis data 
dalam penelitian ini menggunakan program statistik Analysis of Moment Structures (AMOS) versi 6.0.0 dari J.L Arbuckle baik untuk menguji asumsi maupun pengujian hipotesis yang diajukan peneliti.

Asumsi- asumsi yang harus terpenuhi dalam prosedur pengumpulan dan pengolahan data yang dianalisis denga pemodelan SEM adalah menggunakan Kriteria uji kesesuaian yang dapat diringkas dalam tabel 1 berikut.

Tabel 1. Indikasi Goodness -of-Fit

\begin{tabular}{cc}
\hline Goodness of Fit Index & Cut off Value \\
\hline$\chi^{2}-$ chi-squares & Diharapkan kecil \\
Significan probability & $\geq 0,05$ \\
RMSEA & $\leq 0,08$ \\
GFI & $\geq 0,90$ \\
CMIN/DF & $\leq 2,00$ \\
\hline
\end{tabular}

Analisis Faktor Konfirmatori merupakan salah satu metode analisis multivariat yang dapat digunakan untuk mengkonfirmasikan apakah model pengukuran yang dibangun sesuai dengan yang dihipotesiskan. Dalam analisis faktor konfirmatori, terdapat variabel laten dan variabel indikator. Variabel laten adalah variabel yang tidak dapat dibentuk dan dibangun secara langsung sedangkan variabel indikator adalah variabel yang dapat diamati dan diukur secara langsung.

\section{Unidimensionalitas dan Reliabilitas}

Pada tahapan analisis ini, setiap variabel laten dikonfirmasi untuk mendapatkan kejelasan bahwa faktor (variabel laten) benar-benar sesuai dengan apa yang ingin dijelaskan. Pemodelan yang ditujukan untuk mengukur dimensi -dimensi yang membentuk sebuah faktor di sebut model pengukuran (measurement model). Model pengukuran berhubungan dengan sebuah faktor, yaitu apakah variabel-variabel indikator tersebut mempunyai ciri yang sama antara satu dan lainnya (unidimensi) sehingga dapat digunakan untuk mengkonfirmasi sebuah faktor.

Setelah uji kesesuaian model pada setiap variabel-varibel laten, langkah selanjutnya adalah menilai besaran composite reliability konstruk. Reliabilitas adalah ukuran mengenai konsistensi internal dari indikator - indikator sebuah konstruk yang menunjukkan derajat sampai dimana masing-masing indikator itu mengindikasikan sebuah konstruk (faktor) laten. Hasil reliabilitas yang tinggi memberikan keyakinan bahwa indikator-indikator tersebut konsisten dengan pengukurannya. Tingkat reliabilitas yang diterima secara umum adalah $>0,70$.

\section{HASIL DAN PEMBAHASAN}

Variabel konflik pekerjaan - keluarga diukur dengan menggunakan skala / aitem-aitem yang mewakili dimensi-dimensi konflik pekerjaan-keluarga yang terdiri dari 5 dimensi, yaitu: 1) beban kerja, 2) jarak tempat kerja, 3) kondisi tempat kerja, 4) hubungan dengan pimpinan, dan 5) hubungan dengan rekan kerja. 
Langkah pertama adalah melakukan analisis konfirmatori faktor (Confirmatory Factor Analysis / CFA) untuk menguji unidimensionalitas ke-5 indikator pembentuk konstruk Konflik pekerjaan- keluarga. Tabel 2 berikut menunjukkan hasil uji goodness of fit Index (uji kelayakan) CFA tahap pertama dan hasil modifikasi:

Tabel 2. Goodness of Fit Index Konflik Pekerjaan-Keluarga

\begin{tabular}{llllll}
\hline $\begin{array}{l}\text { Goodness of Fit } \\
\text { Index }\end{array}$ & $\begin{array}{l}\text { Cut } \\
\text { Value }\end{array}$ & off & $\begin{array}{l}\text { Hasil } \\
\text { uji 1 }\end{array}$ & $\begin{array}{l}\text { Hasil } \\
\text { Modif }\end{array}$ & $\begin{array}{l}\text { Keterangan } \\
\text { (modif) }\end{array}$ \\
\hline Chi square $\left(\chi^{2}\right)$ & $\begin{array}{l}\text { Diharapkan } \\
\text { kecil }\end{array}$ & 77,470 & 0,037 & \\
& $\geq 0,05$ & 0,000 & 0,848 & Baik \\
Probability & $\geq 0,90$ & 0,952 & 1,000 & Baik \\
GFI & $\leq 0,08$ & 0,085 & 0,000 & Baik \\
RMSEA & $\leq 2,00$ & 3,099 & 0,037 & Baik \\
CMIN/DF & & & & \\
\hline
\end{tabular}

Berdasarkan parameter nilai goodness of fit index pada uji pertama secara umum parameter goodness of fit tergolong kurang baik, sehingga dapat dikatakan CFA tersebut belum fit dan belum terbentuk unidimensionalitas. Modifikasi Indeks (MI) covarians antar eror indikator dipilih MI yang paling besar diantara modifikasi lainnya yang harus dilakukan, karena dengan MI yang paling besar diharapkan terjadi penurunan nilai Chi Square yang cukup berarti dan kenaikan probabilitas eror yang cukup berarti pula sampai model tersebut fit.

Setelah dilakukan modifikasi maka nilai parameter (goodness of fit index) tergolong baik, sehingga dapat dikatakan CFA tersebut sudah fit dan terbentuk unidimensionalitas. Demikian juga uji bobot regresi (loading factor) dari variabel- variabel indikator menunjukkan secara signifikan sebagai dimensi atau indikator dari variabel laten (konflik pekerjaan-keluarga), sebagaimana yang tercantum pada tabel 3.

Tabel 3. Bobot Regresi Konflik Pekerjaan-Keluarga

\begin{tabular}{lcccc}
\hline $\begin{array}{c}\text { Dimensi } \\
\text { (Indikator) }\end{array}$ & $\begin{array}{c}\text { Standar } \\
\text { Error }\end{array}$ & $\begin{array}{c}\text { Standardized } \\
\text { Estimasi }\end{array}$ & P & Keterangan \\
\hline Beban kerja & & 0,393 & $\leq 0,001$ & Signifikan \\
Jarak & 0,162 & 0,493 & $\leq 0,001$ & Signifikan \\
Kondisi & 0,220 & 0,724 & $\leq 0,001$ & Signifikan \\
Pimpinan & 0,268 & 0,890 & $\leq 0,001$ & Signifikan \\
Rekan kerja & 0,285 & 0,792 & $\leq 0,001$ & Signifikan \\
\hline
\end{tabular}




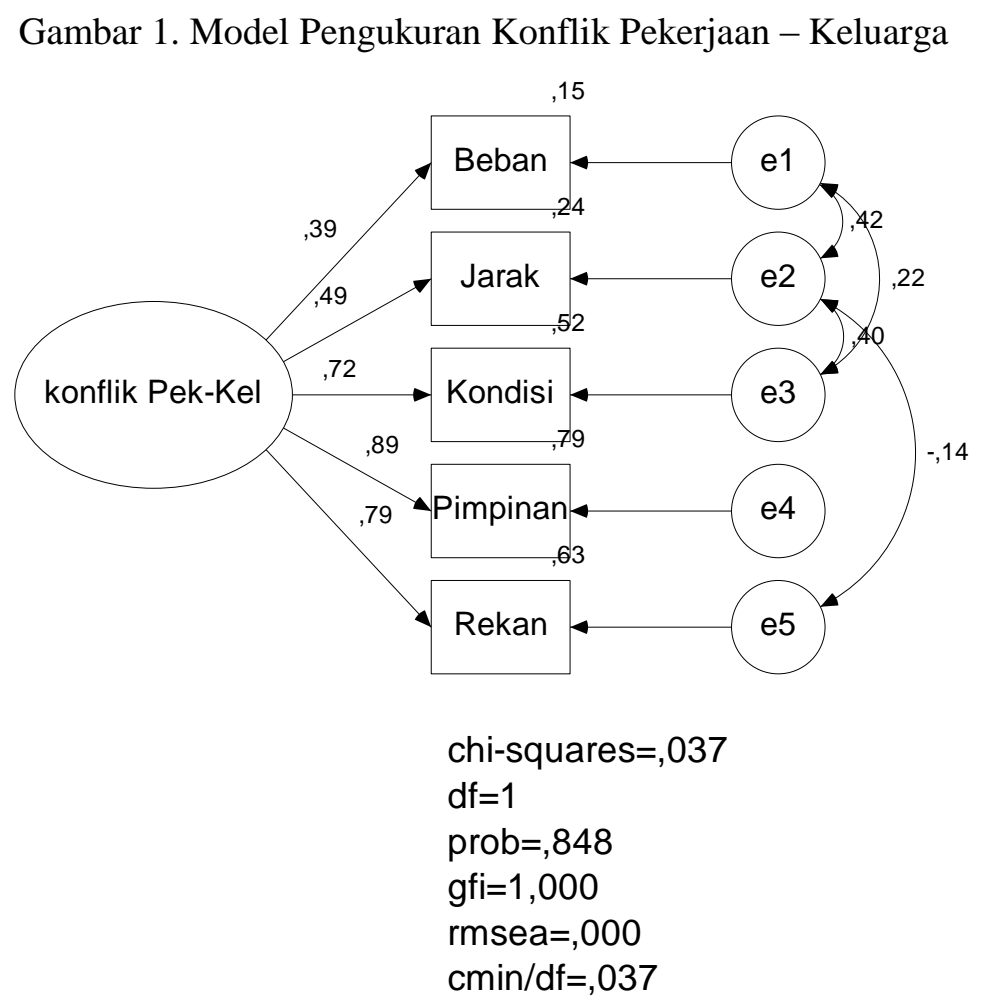

\section{Uji Reliabilitas}

Setelah model fit dievaluasi dan diasumsikan unidimensional maka langkah selanjutnya adalah menghitung besaran Construct-Reliability. Berdasarkan perhitungan dengan standar loading dan measurement error, maka diperoleh nilai construct - reliability konflik pekerjaan-keluarga sebesar: 0,803 .

Penelitian ini dilakukan untuk menguji dimensi-dimensi variabel konflik pekerjaan-keluarga. Masing-masing variabel laten diukur dengan dimensi-dimensi/indikator-indikator. Berdasarkan hasil analisis faktor konfirmatori terhadap ketiga variabel tersebut, secara umum dimensi-dimensi masing-masing variabel memiliki kesesuaian antara dimensi hasil eksplorasi di lapangan sebelumnya dengan data kuantitatif untuk menguji dimensi-dimensi tersebut. Atau dengan kata lain, data kuantitatif dari reponden mengkonfirmasi adanya kesesuaian dengan konstruk yang diajukan sebelumnya.

Setelah konstruk konflik pekerjaan-keluarga diuji analisis faktor konfirmatori menggunakan data dari lapangan, ternyata hasilnya tetap konsisten dengan lima dimensi, yaitu: 1) beban kerja, 2) jarak, 3) kondisi, 4) pimpinan, dan 5) rekan kerja serta memiliki reliabilitas yang memenuhi kriteria, sehingga hasil ini memberi keyakinan bahwa indikator atau dimensi-dimensi konflik pekerjaan-keluarga semua konsisten dengan pengukuranya. Kontribusi terbesar pada variabel konflik pekerjaan-keluarga adalah dimensi rekan kerja dan yang terendah adalah beban kerja. 


\section{KESIMPULAN}

Kesimpulan yang didapatkan dalam penelitian ini di mana dimensi-dimensi/ indikatorindikator penyusun dari variabel laten konflik pekerjaan-keluarga menunjukkan bahwa semua nilai loading factor berpengaruh secara signifikan (unidimensional) terhadap variabel-variabel laten pada Confirmatory Factor Analysis (CFA). Adapun hasilnya tetap konsisten dengan lima dimensi yaitu beban kerja, jarak tempat kerja, kondisi tempat kerja, hubungan dengan pimpinan dan hubungan dengan rekan kerja. Kontribusi terbesar pada variabel konflik pekerjaan-keluarga adalah dimensi rekan kerja dan yang terendah adalah beban kerja.

\section{DAFTAR PUSTAKA}

Badan Pusat Statistik. (2009). Keadaan angkatan kerja di Indonesia. Jakarta: CV Petratama Persada.

Faturochman, Minza, W. M., \& Nurjaman, T. A. (2017). Memahami dan mengembangkan indigenous Ppychology. Yogyakarta: Pustaka Pelajar - Fakultas Psikologi UGM.

Ghozali, I. (2008). Structural equation modeling: Teori, konsep, dan aplikasi dengan program Lisrel 8.80 (2th ed.). Semarang: Badan Penerbit Universitas Diponegoro.

Hammer, L. B., Neal, M. B., Newson, J. T., Brockwood, K. J., \& Colton, C. L. (2005). A longitudinal study of the effects of dual-earner cuoples utilization of family-friedly workplace supports on work and family outcomes. Journal of Applied Psychology, 90(4), 799-810.

Hill, E. J., Yang, C., Hawkins, A. J., \& Ferris, M. (2004). Across- cultural test of the work- family interface in 48 countries. Journal of Marriage and the Family, 66(5), 1300-1316.

Huang, Y. H., Hammer, L. B., Neal, M. B., \& Perrin, N. A. (2004). No Title. Journal of Family and Economic Issues, 25(1), 79-100.

Koentjaraningrat. (1974). Manusia dan kebudayaan di Indonesia. Jakarta: Djambatan.

Noor, M. N. (2002). Work-family conflict, locus of control, and women`s well-being: Tests of altenative pathways. The Journal of Social Psychology, 142(5), 645-662.

Noor, M. N. (2004). Work-family conflict, work-family-role salience, and women`s wellbeing. The Journal of Social Psychology, 144(4), 389-405.

Soeharto, T. N. E., \& Kuncoro, M. W. (2015). Konflik pekerjaan-keluarga pada ibu yang bekerja (dalam keluarga Jawa) ditinjau dari dukungan suami: Pendekatan indigenous. Yogyakarta.

Voydanoff, P. (2004). The Effects of work demands and resources on work-to-family conflict and facilitation. Journal of Marriage and the Famiy, 66, 389-405. 